\author{
Orientasi Kajian Hadis Kontemporer Indonesia
(Studi Artikel E-Jurnal Dalam Portal Moraref 2015-2017) \\ Nailil Huda \\ Fakultas Dirasat Islamiyyah UIN Jakarta \\ naililhuda@uinjkt.ac.id \\ Ade pahrudin \\ Fakultas Dirasat Islamiyyah UIN Jakarta \\ dpahru@gmail.com
}

\begin{abstract}
Abstrak: This study examines the development, orientation and characteristics of the study of contemporary traditions in all online journals PTKI Indonesia on the portal Moraref. According to R. Michel Feener and Daniel Djuned, the study of hadith in Indonesia is growing dynamically and PTKI is at the center of its development. This is contradictory to Martin Van Bruinessen and Ahmad Rafiqi's assertion that the opposite is even less likely to develop. The methodology used by the author is descriptive-content analysis. Where the authors make all the journal articles containing the hadith studies in the Moraref Portal as the main data in the study, in addition to the literature relating to the study of hadith as secondary data. This research found Characteristics of study of Hadith in Indonesia if traced through ejournals that have been indexed Moraref categorized in six categories, namely thematic Hadith Studies with the number of articles 80 articles, Hadith scholarship as many as 74 articles, Studies of Hadits and hadith thinking with 49 articles, as many as 35 articles Hadith Studies orientalisme as many as 36 articles Studies of living hadith as many as 18 articles. So the most dominant in the study of hadith in Indonesia is a thematic research both in religious rituals and social issues.
\end{abstract}

Kata kunci: e-Jurnal Hadis, Hadis kontemporer, Moraref, PTKI, Studi Hadis

\title{
Pendahuluan
}

Ungkapan "Wa laa tamuutunna illa wa antum kaatibuun", menjadi populer dikalangan akademisi jakarta, khususnya para pengkaji Hadis. Tulisan merupakan warisan yang sangat berharga bagi diri penulisnya dan generasi berikutnya. Seandainya dulu para ulama tidak menuliskan pengetahuannya, tentu kita tidak akan mendapatkan kekayaan intelektual seperti saat ini dan 
akan sangat sulit melacak peta keilmuan dan perkembangannya. Dalam sejarah studi Hadis di indonesia abad ke XVII dinilai sebagai awal perkembangan kajian Hadis di indonesia ${ }^{2}$. Penulisan literatur ilmu Hadis di Indonesia memiliki jumlah dan pola yang cukup beragam. Akan tetapi pengulangan topik ulama klasik pada literatur buku diindonesia sangat dominan yang menyebabkan perkembangan ilmu Hadis sangat monoton. Ada anggapan bahwa ilmu Hadis akan mendapatkan perkembangnya di perguruan tingggi. Tepatnya saat studi Hadis tidak hanya diajukan untuk dipelajari, tapi sampai pada tahap pengaplikasian dan penelitian. Atas dasar anggapan tersebutlah kajian ilmu Hadis di perguruan tinggi menjadi amat penting dan menarik untuk diteliti. ${ }^{3}$

\section{Perkembangan Studi Hadis di Indonesia}

a. Paradigma Kajian Hadis

Kajian Hadis tidak tervatas kepada kajian Riwayat dan Dirayat saja, akan tetapi sudah memasuki aspek kesejarahan, pemahaman dan kajian Hadis sarjana barat. Kebangkitan studi Hadis disebabkan oleh beberapa faktor, diantaranya respon terhadap gugatan orientalis terhadap Hadis, terbebasnya negara-negara muslim dari belenggu kolonialis, munculnya paham salafi-takfiri, dan berkembangnya ilmu pengetahuan, sosial dan budaya masyarakat modern.

Para pengkaji Hadis kontemporer lebih terfokus kepada kajian matan Hadis dan pemahamannya. Kajian Sharah Hadis dengan pendekatan hermenetik menjadi sebuah metode yang tren di indonesia seiring berkembangnya filsafat, sosial dan kebahasaan. Semangat kembali kepada Qur'an dan Sunnah harus diimbangi dengan kerangka berpikir yang sistematis dalam memahami Hadis nabi.

b. Perbedaan Metodologi Kajian Hadis; sarjana barat dan timur tengah

Kajian pensharahan Hadis ditimur tengah terpola dengan empat pola; Tahlili, Ijmali, Maudu'i dan Muqaran. Kajian pemahaman Hadis yang bersifat tekstual-normatif, banyak dipengaruhi oleh madhab kebahasaan kufah-Basrah dimasa klasik. Penyelesaian Hadis Mukhtalif menjadi kajian utama sarjana timur dalam pemahaman Hadis. Sentuhan peradaban barat dengan islam pertama kali terjadi pada perang Mu'tah atau pada saat Andalusia direbut oleh bangsa eropa. Sarjana barat atau orientalis mulai menampakkan keseriusannya dalam kritik Hadis pada pertengahan abad ke 19, Goldziher, Schacht, Snouck Hurgonje meragukan keotentikan Hadis dan menawarkan teori baru dalam kritik Hadis, baik sanad maupun matan. Hermeunetik misalnya ditawarkan dalam pemahaman matan, Commonlink ${ }^{4}$ yang dikembangkan Juynball, 
Projecting Back oleh Schacht dalam kritik sanad serta metode kritik Isnad cum matan ala Motzki. ${ }^{5}$

Kajian Hadis diindonesia masih menjadi bagian pembelajaran Quran dan Fikih. Sebelum abad ke 19 kajian Hadis lebih menekankan kepada aspek sanad dan pengumpulan Hadis. Pada abad ke 20, penulisan lebih dengan tujuan pembelajaran ilmu Hadis sebagai pengantar disekolah dan perguruan tinggi, sedangkan pada abad 21 sampai sekarang lebih fokus kepada berbagai pendekatan dalam memahami Hadis Nabi. ${ }^{\top}$

\section{Dinamika Pemikiran Pengkaji Hadis diIndonesia Abad XXI}

a. Awal Perkembangan Studi Hadis di Indonesia

Pada abad XVII para ulama di nusantara mulai merintis kajian mengenai Hadis, Nurudin al-Raniri, Abdul Rauf al-Sinkili dan Muhammad Yusuf al-Makasari. Dan diakhir abad IXX, Sheikh Nawawi (Banten) dan Sheikh Mahfuz\} (Termas) menjadi ulama Hadis nusantarayang diperhitungkan di Mekkah. Penulis mencatat 38 literatur Hadis pada abad XX, karakteristiknya masih bersifat pengantar daripada pembahasan ilmu Hadis. ${ }^{7}$

b. Kriteria Kajian Hadis Masa Modern di Indonesia

Pada awal abad kedua dan ketiga hijriah kriteria kesahihan Hadis belum dibakukan secara rinci. Kriteria kesahihan sanad dan matan baru dirinci belakangan, termasuk bukhari hanya memasukkan Hadis yang sanadnya sahih, hal ini dilihat dari penamaan kitab al-Jami' al- Sahih al-Musnad (Himpunan Hadis yang sahih sanadnya). Kritik matan dengan perbandingan Qur'an dan akal sangat relatif dan subjektif terkait dengan pendekatan pemahaman dan aliran teologis.

Begitupula dalam pemahaman Hadis, ada dua kecenderungan tekstual dan kontekstual. Akan tetapi keduanya tidak dikotomis secara hitam putih akan tetapi sifatnya temporal dan kondisional. Hadis yang tidak lagi komunikatif dengan zaman, maka baru dimaknai dengan kontekstual. Dalam pengukuran kesahihan Hadis, komparasi Hadis dengan al-qur'an juga menjadi halyang sangat penting seperti halnya abu Rayyah dan Muhammad Ghazali. Dalam perkembangannya kajian Hadis pada masa awalnya mengkaji seputar sanad dan arbainaat $^{8}$, di abad dua puluh masuk ke pembahasan ilmu Hadis, dan diabad ke 21 lebih mengarah ke aspek pemahaman Hadis.

Metodologi Pemahaman Hadis di Indonesia

Metode pemahaman Hadis, pertama tradisionalis yang berupa pemahaman Hadis dengan pendekatan tekstual dan kontekstual-historis, dengan memakai pendekatan tekstual dan kontekstual. Kedua, modernis, yaitu 
memahami Hadis-Hadis Rasulullah dengan pendekatan ilmiah dan logikadeduktif (Filosofis).

Dalam perkembangannya pemahaman Hadis dan tafsir bertemu dengan metode hermeneutik, dengan menyaringnya terlebih dahulu diharapkan bisa memberikan pendekatan alternatif. Penulis memberikan contoh Hadis tentang larangan perempuan bepergian jauh tanpa mahramnya. Dalam memahaminya penulis memaparkan bahwa Hadis ini perlu dipahami melalui pendekatan kontekstual dimana mahram bisa menjelma menjadi sistem keamanan, selain menggunakan pendekatan geografis, dimana diindonesia berbeda dengan di arab dan kondisinya juga sudah berbeda dari segi keamanan. Penulis memberikan contoh Hadis lain mengenai kepemimpinan perempuan, Hadis tentang diharamkannya bedah plastik dan Hadis yang berkenaan dengan budaya arab.

Dalam permasalahan Hadis (khususnya di Indonesia), Hadis yang secara sanad bernilai sahih, tetapi tidak sesuai dengan kenyataan sains, atau logika nalar manusia, ternyata para ulama mem/punyai dua pandangan. Pertama, memandang Hadis tersebut tetap berkualitas sahih, hanya saja manusia belum dapat menemukan rahasianya, serta akal manusia belum bisa menggapainya. Kedua, Hadis tersebut tidak sahih, sebab ada illat yang mencacatkannya.

Selanjutnya metode penyelesaian Hadis yang bertentangan dengan sains. Yaitu dengan meneliti validitas Hadis baik sanad maupun matan, selanjutnya ketika sudah dinyatakan valid, maka dilihat konteks ketika Hadis itu disabdakan, kemudian membedah substansi Hadis mushkil tersebut apakah untuk memberi informasi ilmu pengetahuan, ataukah hanya untuk warning dan itibar saja. Tidak lupa juga dipertimbangkan fungsi nabi ketika menyabdakan Hadis itu dan mengelompokkan Hadis tersebut apakah termasuk kedalam ajaran pokok islam, ataukah ajaran yang bersifat ijtihad nabi, atau bahkan bersifat tindakan keseharian nabi sebagai suri tauladan. Dan terakhir menggunakan ayat dan pandangan para ulama yang relevan untuk memperkuat bahan analisis terhadap pemahaman Hadis tersebut.

Perdebatan tentang autentitas dan kevalidan Hadis selalu terjadi diantara para sarjana barat maupun timur, sejak jaman sahabat sampai sekarang. Hal ini disebabkan karena perbedaan metodologi dalam menentukan kesahihan Hadis dikalangan para pengkaji Hadis.

Al-Albānī mendaifkan beberapa Hadis dalam Sahih Muslim, begitu juga dengan Nabia abbot dan Fuat sezgin. Yang membuat kriteria baru dalam standar kritik Hadis. Sementara Cook, Calder, Schacht dan Juynboll meragukan riwayat Hadis Ahad, Commonlink dianggap sebagai sebuah 
rekayasa9. Bahkan Al-Bukhārī pun bisa berpendapat demikian, karena beliau mensyaratkan Liqā’ dalam ketersambungan sanadnya.

Dalam kritik Hadis, kritik sanad dilakukan pertama kali selanjutnya dilakukan kritik matan. Hal ini sangat logis karena sebuah matan tidak bisa disandarkan kepada Nabi kecuali sanadnya tidak sahih. Namun demikian kesahihan/kethiqahan sanad tidak dapat menjamin kesahihan matan secara otomatis. Setidaknya ketika matan dianggap daif/bermasalah, diindikasikan adanya unsur uzur yang timbul dari periwayat matan Hadis. Urgensi kritik matan bukan hanya ditujukan untuk mendeteksi uzur/ketidaksengajaan dari perawi, akan tetapi justru untuk mendeteksi faktor kesengajaan oleh perawi untuk tujuan tertentu dalam Hadis palsu misalnya.

\section{Kritik Matan Hadis}

Embrio dari kritik matan Hadis ini sudah dimulai semenjak masa Rasulullah dengan cara mengkonfirmasi berita kepada Rasul dan atau sahabat yang lain. Selanjutnya kritik matan pada masa sahabat lebih bersifat komparatif, yaitu membandingkan riwayat dengan riwayat sahabat yang lain. Metode komparatif ini berkembang dengan membandingkan riwayat sahabat dengan koleksi tulisan Hadis yang ada dan membandingkannya dengan kandungan al Quran. Kritik matan Hadis pada masa Tabi'īn tidak berbeda jauh dengan pada masa Sahabat, yang membedakan hanyalah motivasi yang melatarbelakanginya, dimana pada masa tabi'īn kritik dilakukan guna untuk membukukan Hadis dan melestarikannya. ${ }^{10}$

Hal ini terjadi juga dengan pemahaman Hadis. Perkembangannya baru terlihat setelah islam berkembang kedaerah-daerah non-arab. Terbukti dengan munculnya kitab-kitab sharah Hadis seperti Tanwīrul hawālik, Fathul bārī dan Faidul bārī.

Selanjutnya para pengkaji Hadis menyusun buku yang berkaitan dengan kritik (Naqd) Hadis dan metodologi pemahaman Hadis. Seperti yang dilakukan oleh Nūr al-Dīn 'Itr dengan karyanya Manhaj an-Naqd Fī Ulūm al-Hadīth, M.M al A'z\{ami dengan studies in hadith and Literatur juga Manhaj al-Naqd 'Inda al-Muhadithīn; Nashatuhū wa Tārikhuhu, Salah al-Din bin Ahmad alIdlibī dalam Manhaj an Naqu al-Mutūn Inda Ulamā al-Hadīth al-Nabawī. Muhammad Thahir al-Jawabī dalam Juhūd al-Muhadithīn fi Naqd Matan alHadith al-Nabawī al-Sharīf. Musfir Abdullah al-Damimī dalam karyanya Maqayīs Naqd Mutūn al-Sunnah. M. Syuhudi Ismail dengan Kaidah Kasahihan Sanad Hadis; Telaah kritis dan Tinjauan Sejarah, Ali Mushtafa Yakub dengan Imam Bukhari dan Metodologi Kritik Hadis, Afif Muhammad dalam Kritik 
Matan;Menuju Pendekatan Kontekstual Pemahaman Hadis Nabi SAW, dan Said Aqil Husin Munawwar dengan Studi Hadis Kontemporer; Rekonstruksi Metodologi atas Kriteria Kesahihan Hadis. Pemahaman Hadis secara khusus terdapat dalam bukunya Syuhudi Ismail Hdis Nabi Yang Tekstual dan Kontekstual, beliau menggunakan istilah Ma'ānil hadith untuk menunjuk kepada pemahaman Hadis.

Kriteria kritik matan yang ditulis oleh para Ulama seperti Khātib alBaghdādī, Ibnu Jauzĩ dan Salahudin al-Idlibī merumuskan empat kriteria pokok; yaitu tidak bertentangan dengan Qur'an, Hadis Nabi yang Sahih, Akal dan Fakta sejarah. Dua yang terakhir masih menjadi perdebatan karena tolok ukur yang tidak pasti. Akal hanya berfungsi untuk menganalisa hal-hal yang bisa diindera oleh panca indera. Oleh karena itu akal tidak dapat atau tidak patut untuk menghakimi kesahihan seuah Hadis, peran akal sesungguhnya adalah dalam hal pemaknaan dan pemahaman Hadis. Al-Qaradhawi misalnya mendasarkan hokum dan pemahaman Teks Shara dalam kerangka Maqāsid Sharīah, di era Kontempoer pemahaman terhadap Hadis harus berdasar kepada multi disiplin Ilmu dan pendekatan dengan menghubungkan aspek terkait (interkonektif) seperti Aspek Historis, Sosiologis, Psikologis, Antropologis, Medis dan Geografis yang mampu menjawab berbagai hikmah dibalik sebuah larangan dan perintah.

Sebagai bahan perbandingan, dalam penafsiran al-Quran terdapat juga Tafsir bil Ra'yi, yaitu menafsirkan Al-Quran dengan menggunakan akal. Terdapat juga tafsir Ilmi, yaitu penafsiran dengan ilmu-ilmu terkait melalui analisa logika. Ketika posisi Hadis sudah disahihkan sanad dan Matannya maka posisinya pun sama sakralnya dengan Al-Quran sebagai sumber ajaran islam. Selanjutnya Hadis pun bisa dijelaskan dengan metode sharh Bil Ra'yi. Dengan memakai berbagai pendekatan yang pas dengan permasalahan ketika mengucapkan teks tersebut. ${ }^{11}$

Sebagai sebuah contoh pemaknaan Hadis dengan melihat konteksnya "pergilah dan jejalilah mulut isteri-isteri mereka dengan debu" Hadis ini perlu dimaknai dengan melihat konteks, karena tidak mungkin memaknainya hanya dengan teks yang ada. Konteks yang terjadi adalah ketika para isteri sahabat menangisi kepergian suaminya dikarenaan gugur dimedan perang mereka tidak berhenti menangis dan nabi memerintahkan seorang sahabat untuk menghentikan tangisan mereka, akan tetapi mereka tidak mau berhenti menangis, sehingga nabi mengucapkan Hadis diatas karena situasi psikologi nabi yang lelah karena berperang. Hal ini yang dimaknai dan dijelaskan oleh 
sahabat Aishah r.a. dalam metodenya mensharah Hadis. Aishah tidak menolak Hadis ini dengan akal sebagaimana yang terjadi dalam kritik Matan.

Demikian fungsi akal dalam pemahaman Hadis nabi. Sesuai dengan fungsi dan kemampuannya yang relevan. Banyak literatur baik yang berbentuk buku dan artikel yang membahas tentang posisi akal dalam kritik matan Hadis dan pemahamannya diantaranya Nur al-Din Itr dengan karyanya Manhaj anNaqd Fi Ulum al-Hadith, M.M al Azami dengan studies in hadith and Literatur juga Manhaj an Naqd 'Inda al-Muhadithin; Nashatuhū wa Tārikhuhu, Salah al-Din bin Ahmad al-Idlibi dalam Manhaj an Naqd al-Mutun Inda Ulama al-Hadith al- Nabawi. Muhammad Thahir al-Jawabi dalam Juhud al-Muhadithin fi Naqd Matan al-Hadith al-Nabawi al-Sharif. Musfir Abdullah al-Damimī dalam karyanya Maqayīs Naqd Mutūn al- Sunnah. M. Syuhudi Ismail dengan Kaidah Kasahihan Sanad Hadis; Telaah kritis dan Tinjauan

Sejarah, Ali Mushtafa Yakub dengan Imam Bukhari dan Metodologi Kritik Hadis, Afif Muhammad dalam Kritik Matan;Menuju Pendekatan Kontekstual Pemahaman Hadis Nabi SAW, dan Said Aqil Husein Munawwar dengan Studi Hadis Kontemporer; ${ }^{12}$

Jonathan Brown dengan Artikelnya How we know early hadith critices did matn criticism and why it's so hard to find it, Christopher Meleheart dengan Bukhari and early hadith criticism dan abdul Ghafur Baloch dengan Key of the Found Upon Inscription Recod of Hadith yang berpendapat bahwa akal mempunyai peran dalam kritik matan Hadis. ${ }^{13}$

Sementra G.H.A Juynball dengan karyanya The autencity of the tradition literature; Discussion in Modern Egypt dan Abu Muzaffar al-San'ani dalam buku al-Hujjah fi Bayani al- Muhajjah berpendapat bahwa akal tidak mampu untuk berperan dalam pengujian kesahihan matan. Berbeda dengan penelitian sebelumnya, penelitian ini ditujukan untuk memposisikan akal pada posisi yang tepat, yaitu pada tahap akhir penelitian (pemahaman Hadis) Metodologi Kritik Hadis Orientalis

1) Metodologi Josep Schacht ${ }^{14}$

Dia dikenal dengan teori Commonlink dan Projecting Backnya dalam kajian sanad Hadis. Dalam penelitian matan dia mengambil kitab al-Maghazi dengan riwayat Zuhri. Dia menolak Hadis yang ada didalamnya karena menurutya Hadis yang menyebutkan bahwa Rasul akan memotong tangan Fatimah jika seandainya mencuri adalah Hadis yang lemah, karena menurutnya ini tidak masuk akal jika tidak ada pengistimewaan bagi keluarga Rasul.

2) Metodologi Cook 
Ia secara khusus membangun teori (Profilation) perkembangan Sanad. Dimana menurutnya sanad sengaja dibuat untuk memperkuat satu matan Hadis yang sama. Menurutnya hal ini bisa terjadi dengan beberpa cara, diantaranya dengan menghilangkan perawi sejaman, dan dengan cara seorang Commonlink menyandarkan Hadis kepada guru yang berbeda serta yang ketiga dengan cara mengabaikan Hadis yang terisolasi.

3) Metodologi Calder

Berbeda dengan orientalis sebelumnya, ia menolak teori Commonlink yang memalsukan Hadis. Menurutnya Commonlink merupakan hasil dari persaingan kelompok pada masa dan sesudah paruh kedua dari abad ketiga Hijriyah. Ketika sebuah matan diterima oleh subuah kelompok kemudian kelompok ini membuatkan sanad untuk matan tersebut.

4) Metodologi G.H.A Juynboll1 ${ }^{15}$

Dalam dating sebuah Hadis, ia selalu mengajukan tiga pertanyaan yaitu dimana, kapan dan oleh siapa Hadis itu disebarkan. Dalam penelitiannya, ia menunjukkan biasanya sanad yang berjalur tunggal adalah perawi ketiga, keempat, dan kelima dari Nabi. Jalur tunggal ini disebut dengan single strand dan murid commonlink disebut dengan partial commonlink. Teori commonlink ini berhubungan erat dengan sistem isnad, dimana abdullah ibn Zubair melakukan pemberontakan pada tahun 63-73 Hijriah terhadap Bani Umayyah, semenjak itu para periwayat Hadis harus menyebutkan sanadnya, maka untuk mengisi kekosongan dari tahun 63 sampai kepada Rasulullah dibuatlah isnadnya.

5) Metodologi Motzki ${ }^{16}$

Menurutnya Commonlink merupakan penghimpun Hadis dan meriwayatkan Hadis secara sistematis. Single strand bukan berarti hanya ada satu jalur sanad saja. Motzki menolak jika Commonlink dianggap sebagai pemalsu Hadis. Karena jika ada pemalsuan, hal itu bisa diketahui dengan membandingkan varian teks dari sanad yang berbeda.

6) Metodologi John Louis Esposito

Ia dikenal sebagai orang yang mengedepankan islam yang universal dan penuh kedamaian dalam beberpa karyanya. Dalam studi Hadis secara tidak langsung memberikan kebebasan kepada rasio untuk memahami maksud teks secara universal, tidak parsial yang sesuai dengan tujuan agama islam, Rahmatan lil 'Alamin. 


\section{Kritik Hadis Diantara Berbagai Metodologi}

Pada umumnya para ulama telah melakukan penelitian Hadis dan menggunakan akal dalam hal keterpenuhan atau tidaknya kesahihan sebuah sanad dan dalam metode memahami sebuah Hadis. Dalam sejarahnya kritik matan Hadis pertama kali ditulis oleh Ibnu Qayyim (1350M) dalam bukunya al-Manār al-Munīf, 400 tahun setelah Ulum al-Hadith berkembang. Kehadiran Kitab ini memberi pengaruh kepada karya-karya sesudahnya diantaranya, Maqāyīs Naqd Mutūn al-Sunnah (1984) yang ditulis oleh Musfir al-Daminī, Juhūd Muhadithīn Fī Naqd Matn al-Hadith al-Nabawi al-Sharif (1986) oleh Muhammad Thahir al-Jawābi, dan al-Sunnah al-Nabawiyyah Baina Ahl Fiqh wa Ahl al-Hadìth oleh Muhammad al-Ghazālī. Anggapan kritik matan belum ditulis secara komprehensif mungkin ada benarnya, akan tetapi secara praktek para ulama Hadis ketika mengkaji kualitas perawi Hadis secara otomatis sebenarnya menguji juga riwayatnya. Dan dalam ilmu Musthalah al-Hadith terdapat istilah yang memfokuskan pada bahasan Matan seperti Maqlub, Mudraj, Shad dan yang lainnya.

Al-Idlibi mensyaratkan kesahihan sanad dengan beberapa kriteria, yaitu tidak bertentangan dengan kandungan Qur'an, tidak bertentangan dengan Hadis Shahih, tidak bertentangan dengan akal, indera dan fakta sejarah. Dan keempat makna Hadis tidak rendah, serampangan tidak menyerupai perkataan nabi.

Literatur ilmu Hadis di Indonesia dalam berbagai model dan pembahasan banyak ditulis oleh intelektual Indonesia, Hasbi Ash Shiddieqy menulis Sejarah dan Pengantar Ulumul Hadits ${ }^{17}$ merupakan buku ilmu Hadis pertama yang ditulis dalam bahasa Indonesia. ${ }^{18}$ Selanjutnya berkembang berbagai model penulisan dalam bidang ini sampai era 2000an, ada model tematik, seperti karya Muhammad Syuhudi Ismail berjudul Kaidah Keshahihan Sanad Hadis, ${ }^{19}$ buku Teori Common Link G.H.A Juynboll Melacak Akar Hadits $\mathrm{Nabi}^{20}$ karya Ali Masrur, dan buku karya Wahyudin Darmalaksana berjudul Hadis di Mata Orientalis: Telaah atas Pandangan Ignaz Goldziher dan Joseph Schacht. ${ }^{21}$ Sebgiannya buku yang berasal dari kumpulan artikel di antaranya karya Ali Musthafa Yaqub dengan buku berjudul Imam Bukhari dan Metodologi Kritik dalam Ilmu Hadis, ${ }^{22}$ begitu juga buku Metodologi Penelitian Living Qur'an dan Hadis, ${ }^{23}$ yang dieditori oleh Sahiron Syamsuddin dan buku berjudul Wacana Studi Hadis Kontemporer, ${ }^{24}$ ditulis oleh Konsorium Tafsir Hadis IAIN Sunan Kalijaga Yogyakarta.

Dalam dekade terakhir, penulisan literatur ilmiah masuk pada era ejurnal yang mulai mengakar di perguruan tinggi. Dosen ${ }^{25}$ sebagai seorang 
pendidik sekaligus peneliti dituntut untuk menulis artikel di jurnal online ${ }^{26}$. Bahkan menjadi persyaratan dalam kenaikan Jabatan Fungsional ${ }^{27}$. Hanya saja beda dulu beda sekarang, kemajuan teknologi dan informasi menjadikan proses penulisan dan penerbitan menjadi sangat mudah. Buku sudah berubah menjadi e-book, jurnal menjadi e-jurnal. Dari full paper menuju paperless ${ }^{28}$

Di perguruan tinggi, selain dosen dituntut untuk menulis artikel jurnal, mahasiswa juga diwajibkan untuk mencari literatur ilmiah dalam setiap mengerjakan tugas-tugas yang diberikan oleh dosen ${ }^{29}$. Bahkan dituntut untuk menulis artikel dijurnal. ${ }^{30}$ Karena e-jurnal mampu menjawab dengan efektif pertanyaan; informasi apa yang paling penting, cara apa yang paling baik dalam mengakses dan mentransformasikannya kembali?. ${ }^{31}$ layanan e- journal di perguruan tinggi memberikan dampak yang besar dalam dunia pendidikan terutama dalam memperoleh informasi ilmiah secara mudah, cepat, dan murah $^{32}$. Hal ini mempengaruhi perkembangan studi Hadis di indonesia, ditambah dengan dibukanya prodi khusus ilmu Hadis setelah keluarnya pembidangan keilmuan dalam KMA No. 36 tahun 2009, di mana studi keilmuan Tafsir Hadis dijadikan dua prodi yakni Ilmu al-Qur'an dan Tafsir serta Ilmu Hadis. Hal ini didukung oleh Keputusan Direktur Jenderal Pendidikan Islam No. 3389 tahun 2013 tentang penamaan perguruan tinggi agama Islam, fakultas dan jurusan pada perguruan tinggi agama Islam ${ }^{33}$.

Artikel pada Scholarly Journal/jurnal ilmiah merupakan intisari dari penelitian keilmuan dibidangnya yang akan melahirkan teori, pendekatan, metode dan kajian yang mengandung keorisinalitasan dan kebaruan. Dan sudah pasti e-jurnal menjadi rujukan ilmiah yang akan banyak dirujuk dalam penelitian studi Hadis. Untuk itu, Kementerian Agama membentuk sebuah portal akademik benama Moraref, yang memuat 417 jurnal PTKI, dengan 27.534 judul artikel yang dapat diakses secara online dengan misi menjadi rujukan literatur dunia islam. ${ }^{34}$ Sekitar lebih dari 250 artikel dalam studi Hadis juga terdapat didalamnya ${ }^{35}$. Ragam dan karakteristiknya bermacam-macam yang merepresentasikan kecenderungan penulisnya dan tren yang sedang ngehits dalam kajian Hadis di indonesia, baik dari segi metodologi, studi tokoh, kritik Hadis, living Hadis, pendekatan alternatif dan pengaruh sarjana timur barat dalam studi Hadis.

Dalam menanggapi hal ini peran E-Jurnal PTKI di Indonesia menjadi elemen terpenting dalam pengembangan studi Hadis di Indonesia. ${ }^{36}$ Dengan mengamini anggapan bahwa pembelajaran ilmu Hadis di Indonesia didominasi perguruan tinggi. Maka dari itu penulis merasa, bahwa meneliti dan menganilis orientasi dan karakteristik studi Hadis di perguruan tinggi melalui jurnal online 
yang diinisiasi oleh Moraref (Kemenag) menjadi hal yang penting. Selain untuk mengetahui perkembangan studi Hadis pada umumnya juga untuk melihat peran e-jurnal PTKI dalam perkembangan studi Hadis di Indonesia.

Penelitian ini memiliki dua permasalahan penting yang akan dijawab. Pertama, bagaimana pengaruh e-jurnal Moraref dalam perkembangan studi Hadis di indonesia? Dan kedua, apa karakteristik pemikiran Hadis kontemporer yang sedang berkembang di indonesia? darimana dan akan kemana?

Penelitian ini sangat signifikan dalam membuktikan teori adanya perkembangan yang perlahan namun pasti dalam studi Hadis di indonesia, serta mengidentifikasi kecenderungan para pengkaji Hadis di indonesia (PTKI) dalam merespon maupun memunculkan isu baru dalam studi Hadis. Terlebih e-jurnal merupakan sarana baru dalam penyebaran karya ilmiah yang orisinal, berbobot dan accesable. Sehingga bisa diketahui keorisinalan ide dan gagasan khas indonesia dalam studi Hadis yang berbeda dengan kajian Hadis timur maupun barat. Ada banyak peneliti yang sudah menulis tentang perkembangan pemikiran Hadis kontemporer di Indonesia, seperti Munirah dengan judul Tesisnya $^{37}$, M. Tasrif dalam bukunya Kajian Hadis diIndonesia: Sejarah dan Pemikiran $^{38}$ dan Hasep Saputra dalam Perkembangan Studi Hadis di Indonesia (Pemetaan dan analisis Geneologi). ${ }^{39}$

Selain dari perkembangan studi Hadis secara umum, beberapa penelitian tentang dinamika studi Hadis di perguruan tinggi yang sangat respon dengan perkembangan teknologi dan paradigma pendidikan juga menjadi perhatian beberapa peneliti, seperti, Alfatih Suryadilaga yang meneliti mengenai Kajian Hadis di Era Global ${ }^{40}$ dan kebijakan di beberapa perguruan tinggi, ${ }^{41}$ begitupun Suryadi ${ }^{42}$ Alfatih Suryadilaga ${ }^{43}$ dan Fadli Lukman ${ }^{44}$ ketiganya memberikan perhatian akan dinamika yang terjadi di perguruan tinggi

1. Peranan e-jurnal dalam Ilmu pengetahuan

a. Pemanfaatan E-Jurnal dalam memenuhi kebutuhan informasi civitas akademik Universitas Hasanudin ${ }^{45}$

b. Mengenal Elektronik Jurnal dan Manfaatnya bagi Pengembangan Karier Pustakawan ${ }^{46}$

c. Peran E-Journal dalam Knowledge Sharing sebagai Basis Pengelolaan Pengetahuan di Universitas Kristen Satya Wacana ${ }^{47}$

\section{Karakteristik Studi Hadis di Indonesia Pada Portal Moraref}

1. Karakteristik Studi Hadis di Indonesia Pada Portal Moraref

Dalam penelitian ini, peneliti mengakses portal moraref dan menemukan 292 artikel Jurnal yang berhasil diunduh dan diteliti dengan cara memasukkan 
term hadith, Hadis, sunnah dan sunah pada menu pencarian judul artikel. Dari artikel-artikel tersebut penulis mengelompokkannya kedalam beberapa kategori berikut. Peneliti juga hanya mengunduh artikel-artikel jurnal yang bisa diunduh, sedangkan yang sulit/tidak bisa diunduh tidak dicantumkan disini karena jumlahnya juga sangat kecil tidak lebih dari $2 \%$ dari artikel yang berhasil terunduh. Dalam penelitian ini, ditemukan bahwa karakteristik studi Hadis di Indonesia terbagi dalam enam kategorisasi,

1. KeIlmuan Hadis sebanyak 74 artikel

2. Studi Hadis orientalisme sebanyak 36 artikel

3. Perkembangan Hadis Indonesia sebanyak 35 artikel

4. Studi living Hadis sebanyak 18 artikel

5. Studi Hadis tematik sebanyak 80 artikel

6. Studi tokoh dan pemikiran Hadis sebanyak 49 artikel

Selanjutnya peneliti akan membahas secara lebih rinci kandungan dari artikel-artikel jurnal tersebut yang terwakili oleh abstrak. Abstak merupakan intisari dari sebuah artikel hasil penelitian. Abstrak paling tidak mengandung tiga hal, yaitu, tujuan/hasil penelitian, Perdebatan akademik dan Metodelogi penelitian.

Peneliti menemukan ada beberapa artikel jurnal yang tidak memuat abstrak penelitian, hal ini sangat disayangkan karena mengurangi kesempurnaan dari layout sebuah jurnal. Kekurangan kedua terletak pada komponen sebuah abstrak, yang mana ada beberapa artikel yang abstraknya tidak mengandung tidak komponen diatas, disamping beberapa ada yang sangat panjang dan sebagian lainnya sangat singkat sekali. Seyogyanya kedepan bisa diselaraskan dan dibuat aturan baku dari pihak pengella jurnal maupun dari pihak moraref selaku pengindeks jurnal-jurnal islamic studies di PTKIN. Pertama, keilmuan Hadis. Hasil penelitian dalam bidang ini meliputi istilah dan teori-teori yang berkaitan dengan Autoritas dan Autentitas Hadis. Kritik Hadis sangat dominan dalam penelitian ini. Kritik Hadis merupakan upaya untuk membuktikan kevalidan sebuah Hadis dengan teori dan metode yang beragam, seperti kritik matan, kritik sanad dan kritik orientalis (dating).

Kedua, Kajian Living Hadis. Kajian ini menggunakan pendekatan dari konteks ke teks, dimana praktik keagamaan yang terjadi dimasyarakat Nusantara dianalisis persepsi semua orang yang terlibat dalam praktik tersebut untuk digali akar teks keagamaan mana yang menjadi sumber dari tradisi tersebut. Tentunya praktik keagamaan tersebut telah mengalami akulturasi budaya dengan masyarakat lokal dan penjelasan dari tokoh agama setempat dalam penafsirannya terhadap teks turut ambil peran dalam pelestarian tradisi 
keagamaan tersebut. Hal ini sebagai alternatif yang ditawarkan para pengkaji Hadis terutama dipelopori oleh para sarjana Hadis UIN Sunan Kalijaga Jogjakarta. Kajian ini melahirkan satu jurnal khusus yang berkaitan dengan tema living Hadis. Dari 18 artikel megenai living Hadis 7 diantaranya berasal dari jurnal Living Hadis. Kajian ini melengkapi kekurangan yang ada pada kajian teks, dengan mengedepankan dan menonjolkan kajian konteks dari pemahaman Hadis itu sendiri. Kajian teks dan konteks saling melengkapi satu sama lain ${ }^{48}$. Teori yang digunakan dalam penelitian ini mengambil dari disiplin ilmu lain, terutama ditinjau dari teori-teori ilmu sosial dan cultural studies ${ }^{49}$

Ketiga, Studi Orientalism Hadis dimana para peneliti indonesia mengangkat pemikiran dan teori yan dikembangkan oleh sarjana barat dalam hal kritik Hadis kontemporer. Hal ini menunjukkan respon yang diberikan oleh para pengkaji Hadis indonesia dalam menanggapi teori-teori kritik Hadis kontemporer yang dikembangkan oleh orientalis (baca; sarjana barat) dalam menguji kembali keotentikan sebuah Hadis baik dari segi sanad maupun dari segi matan Hadis. Jika respon ini dikategorikan ada tiga kategori sikap sarjana Hadis indonesia dalam merespon kritik Hadis sarjana barat, ada yang mendukung, menyangkal dan ada yang mengakomodasi sebagai sebuah bentuk dinamika akademik dalam khazanah ilmu Hadis kontemporer. ${ }^{50}$

Keempat studi tokoh dan pemikiran, mencakup studi tentang tokoh yang mempunyai perhatian terhadap studi Hadis dan pemikiran yang disumbangkannya dalam bidang Hadis. Tokoh-tokoh yang diteliti dalam penelitian-penelitian yang dilakukan tidak terlepas dari tokoh- tokoh yang telah memberikan sumbangan yang signifikan dalam perkembangan studi Hadis di indonesia baik itu pada masa kontemporer maupun pada masa islam klasik, khususnya yang ikut andil dalam perkembangan studi Hadis di Indonesia. ${ }^{51}$

Kelima, perkembangan Hadis indonesia yang membahas dinamika studi Hadis di indonesia baik pada masa awal dan geneologinya maupun dalam hal perkembangan studi kontemporer dan keenam adalah penelitian yang bersifat Hadis tematik, dimana sebuah topik dikaji dalam persfektif Hadis dengan cara mengumpulkan semua Hadis yang berkaitan dengan tema tersebut dengan menjelaskan aspek kebahasaan dan hukum yang diistinbath para ulama dalam masalah tersebut dari para ulama. ${ }^{52}$

Pembahasan yang keenam ini merupakan pembahasan yang paling banyak ditemukan dalam jurnal yaitu sebanyak 80 artikel. Tema-tema yang menjadi kajian penelitian Hadis didalam jurnal-jurnal yang terindeks oleh moraref meliputi Hadis-Hadis yang bertentangan (Mukhtalif Hadis), 
pendidikan, ataupun permasalahan ritual ibadah keagamaan serta Hadis-Hadis yang membahas sosial kemasyarakatan. ${ }^{53}$

\section{Kesimpulan}

Karakteristik kajian Hadis di indonesia jika ditelusuri melalui e-jurnal yang telah terindeks Moraref dikategorisasi dalam enam kategori, yaitu Studi Hadis tematik dengan jumlah artikel 80 artikel, Keilmuan Hadis sebanyak 74 artikel, Studi tokoh dan pemikiran Hadis dengan 49 artikel, Perkembangan Hadis Indonesia sebanyak 35 artikel Studi Hadis orientalisme sebanyak 36 artikel Studi living Hadis sebanyak 18 artikel. Sehingga yang paling dominan dalam penelitian Hadis di indonesia adalah penelitian yang bersifat tematik baik dalam masalah ritual keagamaan maupun sosial kemasyarakatan.

Orientasi kajian Hadis diindonesia kedepan mempunyai prosfek yang cukup signifikan dalam hal kajian living Hadis, dimana kebekuan teks yang cenderung membosankan kini mendapatkan penyegaran dengan adanya pendekatan sebaliknya yaitu pendekatan induktif dari konteks ke konteks. Kajian living Hadis ini sayangnya belum begitu menyebar dan masif, Selain respon terhadap kritik Hadis yang dikembangkan oleh sarjana barat menjadi kajian yang memperoleh porsi yang cukup besar. Terutama dalam merespon teori-teori Autentitas Hadis seperti Commonlink dan Isnad Cum Matan. Penelitian Hadis tematik lebih mengarah kepada tema-tema ritual-sosial yang selalu menjadi polemik dimasyarakat.

Moraref sebagai pengindeks jurnal-jurnal PTAI yang berada dibawah kemenag mempunyai peranan yang cukup signifikan dalam menanggapi era digitalisasi karya ilmiah sehingga mudah untuk diakses oleh para akademisi sehingga kajian Hadis akan selalu berkembang. Selain dari meningkatnya kuantitas karya ilmiah juga mendongkrak kualitas karya ilmiah yang dihasilkan. Pengawasan dan upaya peningkatan mutu jurnal yang terindeks juga perlu dipergatikan. Peneliti melihat adanya beberpa jurnal yang masih belum baku dalam layout jurnal, seperti ada yang masih dalam bentuk makalah, tidak adanya informasi nama jurnal, volume jurnal dalam lembaran artikel. Abstrak artikel juga masih belum dilengkapi oleh beberapa jurnal, sehingga ada beberapa artikel yang tidak terdapat abstraknya. Untuk masalah akses juga perlu diperhatikan agar jurnal elektronik yang berfungsi sebagai alat diseminasi/penyebaran ilmu pengetahuan bisa berjalan dengan baik. Peneliti ketika mencoba akan mengunduh dan masuk ke website jurnal yng dituju tidak bisa mengaksesnya, baik karena harus mengisi password maupun tidak dapat diakses sama sekali. Seyogyanya semua artikel jurnal bisa diakses dengan mudah 
dan free untuk terus menumbuhkan dinamika perkembangan pengetahuan.

\section{Daftar Pustaka}

\section{- Sumber Buku}

Ali Masrur, Teori Common Link G.H.A Juynboll Melacak Akar Hadits Nabi, cetakan 3 (Yogyakarta: LKIS, 2013).

Ali Musthafa Yaequb, Imam Bukhari dan Metodologi Kritik dalam Ilmu Hadis (Jakarta: Pustaka Firdaus, 1991)..

Amir Mahmud (ed.), Wacana Studi Hadis Kontemporer (Yogyakarta: Tiara Wacana Yogya, 2002).

M. Tasrif, Kajian Hadis di Indonesia: Sejarah dan Pemikiran (STAIN Ponorogo Press : 2007) Muhammad Syuhudi Ismail, Kaidah Keshahihan Sanad Hadis (Jakarta: Bulan Bintang, 1995).

Sahiron Syamsuddin, Metodologi Penelitian Living Qur'an dan Hadis (Yogyakarta: TH Press \& Teras, 2007).

T.M. Hasbi Ash Shiddieqy, Sejarah dan Pengantar Ulumul Hadis, cetakan 10 (Jakarta: Bulan Bintang, 1991).

Wahyudin Darmalaksana, Hadis di Mata Orientalis: Telaah atas Pandangan Ignaz Goldziher dan Joseph Schacht (Bandung: Benang Merah Press, 2004).

\section{- $\quad$ Sumber Peraturan Menteri}

Permen Ristekdikti RI no 2 tahun 2016 permenristek dikti no 20 tahun 2017

Permen Pan-RB No 17 Tahun 2013 Jo. No 46 Tahun 2013 Tentang Jabatan Fungsional dosen dan Angka Kreditnya

Uu no 12/2012 Dikti

\section{- $\quad$ Sumber Disertasi, Tesis, Skripsi}

Hasep Saputra, Perkembangan Studi Hadis di Indonesia (Pemetaan dan Analisis Geneologi) Disertasi UIN Jakarta, 2014

Munirah, Metodologi Sharah Hadis di Indonesia Awal abad ke 20 (Tesis Prodi Agama dan Filsafat konsentrasi Qur'an Hadis UIN Sunan Kalijaga :2015)

Qibtiyatul Maisaroh, Kajian Ilmu Hadis di Pergurun Tinggi (Studi atas Karya Tesis di UIN Sunan Kalijaga Tahun 1990-2010), Skripsi IAIN Surakarta, Tahun 2017

\section{- $\quad$ Sumber Jurnal Ilmiah}

Abdullah, M. Robith Fuadi. "Meninjau Hukuman Mati Bagi Murtad (Kajian Hadist Tematik)." Journal de Jure 4, no. 1 (June 1, 2012).

Ahmad, Arifuddin, Andi Muhammad Ali Amiruddin, and Abdul Gaffar. "Kecenderungan Kajian Hadith Di UIN Alauddin Makassar (Tracer Study 
Terhadap Skripsi Mahasiswa Tahun 1994-2013).” JOURNAL OF QUR'AN AND HADITH STUDIES 4, no. 2 (December 20, 2015): 249-266.

Akib, Nasri. "KESAHIHAN SANAD DAN MATAN HADITS: KAJIAN ILMUILMU SOSIAL." Shautut Tarbiyah 21, no. 1 (May 1, 2009): 102-119.

Alamsyah, Alamsyah. "DINAMIKA OTORITAS SUNNAH NABI SEBAGAI SUMBER HUKUM ISLAM.” AL-'ADALAH 12, no. 1 (February 28, 2017): 479-492.

Ali, Muhamad. "Kajian Naskah Dan Kajian Living Qur'an Dan Living Hadith." JOURNAL OF QUR'AN AND HADITH STUDIES 4, no. 2 (December 20, 2015): 147-167.

Amrulloh, A. "EKSISTENSI KRITIK MATAN MASA AWAL: Membaca Temuan Dan Kontribusi Jonathan Brown.” Kontemplasi: Jurnal Ilmu-Ilmu Ushuluddin 4, no. 1 (August 1, 2015).

Andi, Andi. "MANHAJ MUHAMMAD NASHIRUDDIN AL-ALBANI DALAM MENDAIFKAN HADIS: Telaah Kitab Dha'if Al-Adab Al-Mufrad." ATTAHDIS: Journal of Hadith Studies 1, no. 2 (July 1, 2017). Ansor, Muhammad. "ISLAM AWAL, RIDDAH, DAN PRAKSIS KEBEBASAN BERAGAMA: REINTERPRETASI HADIS MAN BADDAL DINNAH FAQTULÛH.” Mutawatir 5, no. 2 (September 28, 2016): 273-296.

Djuwita, Warni. "ANAK DAN PENDIDIKAN ANAK USIA DINI DALAM CAKRAWALA AL-QUR'AN-HADIS.” Ulumuna 15, no. 1 (June 30, 2011): 119-140.

Husna, Muhammad Najmil. "Kritik Matan Hadis Muhammad Syahrūr.” Al - Ikhtibar: Jurnal Ilmu Pendidikan 3, no. 2 (March 1, 2017): 113-135.

Idri, Idri. "Kritik Had?th dalam Perspektif Studi Kontemporer." ISLAMICA: Jurnal Studi Keislaman 4, no. 2 (January 22, 2014): 261-279.

Irham, Masturi. "Sejarah Dan Perkembangan Kritik Matn Hadis.” Mutawatir 1, no. 1 (September 8, 2015): 96-112.

Jati, Wasisto Raharjo. “Tradisi, Sunnah Dan Bid'ah: Analisa Barzanji Dalam Perspektif Cultural Studies." El-HARAKAH (TERAKREDITASI) 14, no. 2 (June 26, 2013).

Jayadi, M. "Perkembangan Literatur Hadis pada Masa Awal Islam.” Khizanah alHikmah Jurnal Ilmu Perpustakaan, Informasi, dan Kearsipan 3, no. 1 (June 23, 2015): 65-78.

Juriono, Juriono. "METODE KRITIK MATAN MUSHTHAFA AS-SIBA'I DALAM KITAB AS-SUNNAH WA MAKANATUHA FI AT-TASYRI‘AL-ISLAMI.” AT-TAHDIS:

Journal of Hadith Studies 1, no. 1 (March 31, 2017). Accessed October 18, 2017. Karyadi, Fathurrahman. "MENGKAJI (BUDAYA) SANAD ULAMA TANAH JAWA.” 
THAQAFIYYAT: Jurnal Bahasa, Peradaban dan Informasi Islam 14, no. 1 (February 7, 2016): 58-69.

Kurniati, Kurniati. "Nepotisme dalam Perspektif Hadis (Kritik Sanad dan Matan Hadis).” Al Daulah : Jurnal Hukum Pidana dan Ketatanegaraan 4, no. 1 (June 20, 2015): 116-129.

Luthfi, Khabibi Muhammad. "KRITIK MATN SEBAGAI METODE UTAMA DALAM PENELITIAN KESAHIHAN HADIS NABI.” Islamic Review: Jurnal Riset dan Kajian Keislaman 2, no. 3 (September 25, 2016): 481-506.

Ma'ani, Bahrul. "Al-Jarh Wa Al-Ta'dil: Upaya Menghindari Skeptis Dan Hadis Palsu." Media Akademika 25, no. 2 (April 18, 2010).

Ma'mun, Muhammad. "DARI MUIR HINGGA MOTZKI: Hadits dan Asal-usul Hukum Islam dalam Diskursus Orientalisme.” AL-AHWAL 5, no. 1 (2013).

Marzuki, Azro'i. "MEMELIHARA KEOTENTIKAN HADITS MELALUI KRITIK SANAD.” TAJDID 9, no. 1 (November 17, 2015).

Masrur, Ali. "PENERAPAN METODE TRADITION-HISTORICAL DALAM MUȘANNAF 'ABD AL-RAZZĀQ AL-ȘAN'ĀNI DAN IMPLIKASINYA TERHADAP PERSOALAN DATING HADIS DAN PERKEMBANGAN FIKIH MEKKAH.” Jurnal THEOLOGIA 24, no. 1 (2013): 175-200.

Maswara, Husen. "KRITIK MATAN HADIS DI KALANGAN SAHABAT." TAHKIM 9, no.

2 (August 14, 2016).

Materu, Ruslan Daeng. "KESAHIHAN SANAD HADIS (KOMBINASI METODE ANALISISISNAD KESARJANAAN MUSLIM DENGANNON MUSLIM) Validityof Sanad Hadith \{Combination Method of Analysis of MoslemIsnad Scholarship With Non-Moslem).” Al-Qalam 17, no. 1 (June 1, 2011): 82-92.

Matswah, Akrimi. "HERMENEUTIKA NEGOSIATIF KHALED M. ABOU EL FADL TERHADAP HADIS NABI.” ADDIN 7, no. 2 (November 14, 2015).

Moh, Muhtador. "MELACAK OTENTISITAS HUKUM ISLAM DALAM HADIS NABI (STUDI PEMIKIRAN JOSEPHT SCHACHT).” ISTINBATH : Jurnal Hukum 14, no. 1 (May 5, 2017): 35-47.

Mudhiiah, Khoridatul. "PEMIKIRAN DAUD RASYID TERHADAP UPAYA INGKAR SUNNAH KELOMPOK ORIENTALIS DI INDONESIA.” ADDIN 7, no. 2 (November 14, 2013).

Muhtador, Mohamad. "Membaca Perempuan Dalam Hadis Misoginis: Usaha Kontekstualisasi Nilai Kemanusiaan | Muhtador | BUANA GENDER : Jurnal Studi Gender Dan Anak" (n.d.).

Muksin, Ucin. "Al-Hadits dalam Pandangan Orientalis (Joseph Schacht)." Ilmu Dakwah: Academic Journal for Homiletic Studies 4, no. 11 (September 1, 2015): 111-122. 
Muna, Arif Chasanul. "ANALISA MATAN BERAGAM VERSI: REKONSTRUKSI TERHADAP METODE MUHADDITSÛN.” JURNAL PENELITIAN 6, no. 2 (May 21, 2013).

Nadhiran, Hedhri. "KRITIK SANAD HADIS: Tela'ah Metodologis." Jurnal Ilmu Agama 15, no. 1 (April 16, 2016): 91-109.

Nasution, Amir Hamzah. "KONTRIBUSI PEMIKIRAN YUSUF AL-QARADAWI DALAM KITAB KAIFA NATA'AMAL MA'A AS-SUNNAH NABAWIYAH." AT-TAHDIS: Journal of Hadith Studies 1, no. 1 (March 31, 2017).

Putra, Afriadi. "Pemikiran Hadis KH. M. Hasyim Asy'ari dan Kontribusinya terhadap Kajian Hadis di Indonesia." Wawasan: Jurnal Ilmiah Agama dan Sosial Budaya 1, no. 1 (February 2, 2016): 46-55.

Rasjidin, Sjafri. "METODOLOGI KRITIK MATAN DALAM KITAB ALMAUDHU'AT KARYA IBN AL-JAUZI.” MEDIASI 9, no. 2 (August 24, 2016).

Ritonga, Ahmadi. "KONTRIBUSI PEMIKIRAN 'ALA' AD-DIN IBN AHMAD ALIDLIBI DALAM METODE KRITIK MATAN HADIS.” AT-TAHDIS: Journal of Hadith Studies 1, no. 1 (March 31, 2017).

Rohmansyah, Rohmansyah. "HADIS DAN SUNNAH DALAM PERSPEKTIF IGNAZ GOLDZIHER.” ULUL ALBAB Jurnal Studi Islam 16, no. 2 (December 30, 2015): 235-248.

Sanaky, Hujair AH. "Pemikiran Fazlur Rahman Tentang Metodologi Sunnah Dan Hadis [Kajian Buku Islamic Methodology in History] | Sanaky | Al-Mawarid" (n.d.).

Siregar, Dame. "Krtik Matan Hadis-Hadis Tentang Bid'ah." TAZKIR: Jurnal Penelitian Ilmu- ilmu Sosial dan Keislaman 1, no. 2 (December 1, 2015): 9173.

Sunusi, Sunusi. "Masa Depan Hadis Dan Ulum Hadis." Al-Hikmah Journal for Religious Studies 14, no. 1 (June 13, 2013): 65-81.

Supian, Aan. "Kontribusi Pemikiran Hasbi Ash-Shiddieqy Dalam Kajian Ilmu Hadis." Mutawatir 4, no. 2 (December 1, 2014): 270-291.

- "STUDI HADIS DI KALANGAN ORIENTALISME." Nuansa 9, no. 1 (June 10, 2016). Suryadi, Mr. "REKONSTRUKSI KRITIK SANAD DAN MATAN DALAM STUDI HADIS." ESENSIA: Jurnal Ilmu-Ilmu Ushuluddin 16, no. 2 (October 1, 2015).

Suryadilaga, Muhammad Alfatih. "Mafhūm Al-Ṣalawāt 'inda Majmū'at Joged Shalawat Mataram: Dirāsah Fì Al-Hadìth Al-Hayy.” Studia Islamika 21, no. 3 (December 30, 2014): 535-578.

. "Ragam Studi Hadis Di PTKIN Indonesia Dan Karakteristiknya: Studi Atas Kurikulum IAIN Bukittinggi, IAIN Batusangkar, UIN Sunan Kalijaga, Dan IAIN Jember." JOURNAL OF QUR'AN AND HADITH STUDIES 4, no. 2 (December 20, 2015): 215-247. 
Umayah, Umayah. "JANGAN MARAH! (ANALISIS SANAD DAN MATAN HADIS) OLEH: UMAYAH.” Diya Al-Afkar: Jurnal Studi al-Quran dan alHadis 2, no. 01 (June 1, 2014)..

Yaqub, Ali Mustafa. "Autentisitas Dan Otoritas Hadis Dalam Khazanah Keilmuan Ulama Muslim Dan Sarjana Barat.” Tarjih: Jurnal Tarjih dan Pengembangan Pemikiran Islam 7, no. 1 (February 16, 2017): 33-41.

Zarkasih, Zarkasih. "Inkar Sunah: Asal Usul dan Perkembangan Pemikiran Inkar Sunah di Dunia Islam.” TOLERANSI 4, no. 1 (May 10, 2012): 81-96.

\section{Catatan Akhir}

1. Ungkapan tersebut menjadi "Fatwa" Ali mustafa Yakub kepada para murid dan mahasiswanya, beliau adalah seorang guru besar Hadis IIQ dan pendiri Daar sunnah ciputat, yang berarti janganlah kalian meninggal dunia kecuali kalian telah menjadi penulis yang meninggalkan tulisannya untuk generasi berikutnya.

2. Hasep Saputra, Perkembangan Studi Hadis di Indonesia (Pemetaan dan Analisis Geneologi) Disertasi UIN Jakarta, 2014 hal 88

3. Qibtiyatul Maisaroh, Kajian Ilmu Hadis di Pergurun Tinggi (Studi atas Karya Tesis di UIN Sunan Kalijaga Tahun 1990-2010), Skripsi IAIN Surakarta, Tahun 2017, Hal 5

4. lihat lebih jelas Nur Mahmudah, "Pemikiran G. H. A. Juynboll Tentang Hadis," Mutawatir 3, no. 1 (June 1, 2013): 106-122.

5. Baca selengkapnya Ali Masrur, "Penerapan Metode Tradition-Historical Dalam Mușannaf 'Abd Al-Razzāq Al-Ṣan 'Ānī Dan Implikasinya Terhadap Persoalan Dating Hadis Dan Perkembangan Fikih Mekkah,” Jurnal THEOLOGIA 24, no. 1 (2013): 175-200.

6. selengkapnya baca Howard Federspiel, “'Hadit' Literature In Twentieth Century Indonesia," Oriente Moderno 21 (82), no. 1 (2002): 115-124.

7. lihat disertasi Saputra, "Perkembangan Studi Hadis Di Indonesia (Pemetaan Dan Analisis Geneologi)."

8. lihat Evie Hidayati, "Metodologi Ahmad Lutfi Fathullah Dalam Penyusunan Kitab Hadis Arba'in: Telaah Terhadap Buku 40 Hadis Mudah Dibaca Sanad Dan Matan," AT- TAHDIS: Journal of Hadith Studies 1, no. 1 (March 31, 2017): 37-38,

9. lihat Arif Chasanul Muna, "Kritik Pandangan G.H.A. Juynboll Terhadap Ilmu Al-Jarh Wa Al- Ta'dil,” KALIMAH 14, no. 1 (March 31, 2016): 13-36.

10. lihat untuk lebih jelas Khabibi Muhammad Luthfi, "Kritik Matn Sebagai Metode Utama Dalam Penelitian Kesahihan Hadis Nabi," Islamic Review: Jurnal Riset dan Kajian Keislaman 2, no. 3 (September 25, 2016): 481-506.

11. Lihat Disertasi Uswatun Hasanah, "Kritik Atas Kritik Matan Hadis Al Idlibi (Telaah Atas Kriteria Matan Sahih Bersesuaian Akal)," n.d.

12. Lihat Latar Belakang Disertasi ibid.

13. Lihat A. Amrulloh, "EKSISTENSI KRITIK MATAN MASA AWAL: Membaca 
Temuan Dan Kontribusi Jonathan Brown,” Kontemplasi: Jurnal Ilmu-Ilmu Ushuluddin 4, no. 1 (August 1, 2015), accessed October 8, 2017, http://ejournal.iaintulungagung.ac.id/index.php/kon/article/view/127.

14. Muhtador Moh, "Melacak Otentisitas Hukum Islam Dalam Hadis Nabi (Studi Pemikiran Josepht Schacht)," ISTINBATH : Jurnal Hukum 14, no. 1 (May 5, 2017): $35-47$.

15. Mahmudah, "Pemikiran G. H. A. Juynboll Tentang Hadis."

16. Masrur, "Penerapan Metode Tradition-Historical Dalam Mușannaf 'Abd Al-Razzāq Al-Ṣan 'Ānī Dan Implikasinya Terhadap Persoalan Dating Hadis Dan Perkembangan Fikih Mekkah.”

17. T.M. Hasbi Ash Shiddieqy, Sejarah dan Pengantar Ulumul Hadis, cetakan 10 (Jakarta: Bulan Bintang, 1991).

18. Sebelum Hasbi literatur ilmu Hadis yang ditulis oleh ulama Indonesia adalah literatur berbahasa Arab, seperti yang tulis oleh Mahfudz At-Tirmasi (w. 1919/20 M) berjudul Manhaj Dzaw an- Nazhar: Syarh Manzhumah 'Ilm Al-Atsar karya ini merupakan syarh terhadap karya As-Suyuthi dan karya yang ditulis Mahmud Yunus berjudul Ilmu Musthalah al-Hadis (Surabaya: As-Sa"diyah, 1940).

19. Muhammad Syuhudi Ismail, Kaidah Keshahihan Sanad Hadis (Jakarta: Bulan Bintang, 1995). Buku ini merupakan disertasi di UIN Syarif Hidayatullah Jakarta,

20. Ali Masrur, Teori Common Link G.H.A Juynboll Melacak Akar Hadits Nabi, cetakan 3 (Yogyakarta: LKIS, 2013). Buku ini merupakan disertasi di IAIN (sekarang UIN) Sunan Kalijaga Yogyakarta.

21. Wahyudin Darmalaksana, Hadis di Mata Orientalis: Telaah atas Pandangan Ignaz Goldziher dan Joseph Schacht (Bandung: Benang Merah Press, 2004).

22. Ali Musthafa Ya"qub, Imam Bukhari dan Metodologi Kritik dalam Ilmu Hadis (Jakarta: Pustaka Firdaus, 1991)..

23. Sahiron Syamsuddin, Metodologi Penelitian Living Qur'an dan Hadis (Yogyakarta: TH Press \& Teras, 2007). Buku ini merupakan kumpulan artikel tentang living Qur'an dan Hadis.

24. Amir Mahmud (ed.), Wacana Studi Hadis Kontemporer (Yogyakarta: Tiara Wacana Yogya, 2002). Buku ini merupakan bunga rampai yang dikumpulkan dari berbagai tulisan, termasuk beberapa tulisan terjemahan.

25. Dosen adalah pendidik profesional dan ilmuwan dengan tugas utama mentransformasikan, mengembangkan,dan menyebarluaskan Ilmu Pengetahuan dan Teknologi melalui Pendidikan, Penelitian, dan Pengabdian kepada Masyarakat. Lihat Peraturan Menteri ristek dikti RI no 2 tahun 2016 pasal 1 poin 1.

26. Lihat Uu no 12/2012 Dikti dan permenristek dikti no 20 tahun 2017

27. Lihat Permen Pan-RB No 17 Tahun 2013 Jo. No 46 Tahun 2013 Tentang Jabatan Fungsional dosen dan Angka Kreditnya

28. Lihat Permen Pan-RB No 17 Tahun 2013 Jo. No 46 Tahun 2013 Tentang Jabatan Fungsional dosen dan Angka Kreditnya 
29. Lihat Riah Wiratningsih, Pemanfaatan E-Journal dalam Menumbuhkan Suasana Akademik di Perguruan Tinggi, (Artikel Pemenang Finalis V dalam Lomba Penulisan Artikel Pustaka Tingkat Nasional, 2011 : "Manfaat dan pemanfaatan E-Journal”)

30. Lihat Surat Edaran Dirjen Kemendikbud Nomor 152/E/T/2012

31. Lihat Safrian Aswati. dkk, Peranan Sistem Informasi dalam Perguruan Tinggi, Jurnal Teknologi dan Informasi. Volume I nomor 2 Maret 2015, hal 79

32. Mustati dan Mujib, Pemanfaatan E-Jurnal dalam memenuhi kebutuhan informasi civitas akademik Universitas Hasanudin, Jurnal Komunikasi KAREBA, Vol 2 no 1, Tahun 2013. Hal. 102

33. Muhammad Alfatih Suryadilaga, Ragam Studi Hadis di PTKIN Indonesia dan Karakteristiknya: Studi atas Kurikulum IAIN Bukittinggi, IAIN Batusangkar, UIN Sunan Kalijaga, dan IAIN Jember, Journal of Qur'an and Hadith Studies: Vol. 4, No. 2, 2015. Hal 216

34. www.kemenag.go.id, dengan judul artikel "kemenag kembangkan jurnal online melalui Moraref"

35. Moraref.or.id, di akses 11 Mei 2017 pukul 11.22

36. Qibtiyatul Maisaroh, Kajian Ilmu Hadis di Pergurun Tinggi (Studi atas Karya Tesis di UIN Sunan Kalijaga Tahun 1990-2010), Skripsi IAIN Surakarta 2017. Hal 6

37. Lihat Munirah, Metodologi Sharah Hadis di Indonesia Awal abad ke 20 (Tesis Prodi Agama dan Filsafat konsentrasi Qur'an Hadis UIN Sunan Kalijaga :2015) Tesis ini berbicara seputar perkembangan dan sejarah Sharah Hadis secara umum khususnya di indonesia. Kitab al-Khil'ah al- Fikriyah bi Sharh al-Minhah al-Khairiyah Karya Mahfuz al-Tirmasi dan kitab al-Tabyin al-Rawi Sharh Arba'in al-Nawawi karya Kasyful Anwar menjadi studi kasus dalam mengelaborasi teori sharah Hadis. Tesis ini mengidentifikasi metodologi Sharh Hadis di Indonesia, namun hanya terbatas pada awal abad ke-20.

38. Lihat M. Tasrif, Kajian Hadis di Indonesia: Sejarah dan Pemikiran (STAIN Ponorogo Press : 2007) Buku ini membahas tentang sejarah dan perkembangan literatur Hadis sejak abad XVII sampai akhir abad XX, meliputi perkembangannya di madrasah dan di perguruan tinggi sampai akhir abad XX. Dilengkapi dengan kedudukan Hadis dan metode pemahamannya. Kelebihan buku ini pembahasannya merujuk kepada penelitian sebelumnya, namun kekurangannya hanya sampai abad XX saja.

39. Lihat Hasep Saputra, Perkembangan Studi Hadis di Indonesia (Pemetaan dan analisis Geneologi) (UIN Jakarta press :2014). Disertasi ini meneliti pemetaan metodologi pemahaman Hadis di indonesia dengan mencari geneologi pemikiran para pengkaji Hadis indonesia dari segi keterpengaruhannya dari studi Hadis di barat dan timur, dan berusaha mencari kebaruan pemikiran/gagasan dari para pengkaji Hadis di indonesia. Karya ilmiah ini memberikan sumbangan pemikiran yang cukup signifikan dalam upaya pemetaan studi Hadis diindonesia, namun studi tentang geneologi pemikiran pengkaji Hadis terlalu dominan didalamnya.

40. Muhammad Alfatih Suryadilaga, Kajian Hadis di Era Global, Jurnal Esensia Vol 15 No 22014 Artikel ini membahas penggunaan internet dan software khusus dalam pengkajian Hadis sehingga melahirkan metode baru dalam penelitian Hadis, berbagai 
bentuk kajian global dielaborasi oleh penulis dan menyinggung peran jurnal ilmiah dalam hal ini.

41. Muhammad Alfatih Suryadilaga, Ragam Studi Hadis di PTKIN Indonesia dan Karakteristiknya: Studi atas Kurikulum IAIN Bukittinggi, IAIN Batusangkar, UIN Sunan Kalijaga, dan IAIN Jember, Journal of Qur'an and Hadith Studies: Vol. 4, No. 2, 2015 Artikel ini menganalisis karakteristik studi Hadis melalui kurikulum yang berjalan di prodi ilmu Hadis yang baru di buka dibeberapa PTAIN, dengan studi kasus 3 PTAIN. Penelitian ini menyimpulkan bahwa ada tiga aspek studi yang dikembangkan; Ulum al-Hadith, metodologi pemahaman Hadis, dan metode penelitian Hadis.

42. Suryadi, Prospek Studi Hadis di Indonesia (Telaah atas kajian Hadis di UIN, IAIN, STAIN), Jurnal Studi Ilmu-ilmu Al-Qur'an dan Hadis, Vol 16 no 2, 2014 Ide utama yang coba digagas oleh artikel ini adalah untuk merespon dibukanya prodi Hadis di beberapa PTAIN berdasar KMA dan Keputusan Dirjen Pendis dan menekankan kecilnya prospek studi Hadis di PTAIN. Reintegrasi prodi Hadis ketafsir merupakan solusi yang ditawarkan. Artikel ini terbatas kepada perguruan tinggi Agama Islam negeri tidak mencakup PTKI secara keseluruhan dan bertolak belakang dengan ide yang akan peneliti ajukan.

43. Muhammad Alfatih Suryadilaga, Profil Prodi Ilmu Hadis di Era Globalisasi Teknologi Informasi, Riwayah: Jurnal Studi Hadis Vol 2 No 12016

44. Fadli Lukman, Integrasi-Interkoneksi dalam Studi Hadis Disertasi UIN Sunan Kalijaga Yogyakarya, Religia: Jurnal STAIN Pekalongan, Vol 19 No 2 2016. Tujuan utama karya ilmiah ini untuk mengetahui sejauh mana konsep integrasi-interkoneksi studi islam yang digagas oleh Amin Abdullah telah berjalan. Disertasi-disertasi dalam studi Hadis menjadi studi kasusnya, dan hasilnya lebih dari 60 persen disertasi sudah menggunakan pendekan sosio-humaniora seperti yang dikembangkan dibarat. Sumber data yang digunakan dan ruang lingkup penelitian menjadi hal yang sangat beda dengan penelitian ini.

45. Mustati dan Mujib, Pemanfaatan E-Jurnal dalam memenuhi kebutuhan informasi civitas akademik Universitas Hasanudin, Jurnal Komunikasi KAREBA Vol 2 no 1 2013Artikel ini menyoroti peran jurnal online dalam memenuhi kebutuhan para civitas akademik UNHAS, dimana jurnal mempunyai peran yang praktis dan signifikan dalam membantu proses transformasi pengetahuan. Sementara penelitian ini fokus terhadap kajian studi Hadis

46. Jamaluddin, Mengenal Elektronik Jurnal dan Manfaatnya bagi Pengembangan Karier Pustakawan, Jurnal JUPITER Vol. 14 No.2 (2015) E-jurnal tidak hanya bisa dimanfaatkan oleh para civitas akademik, akan tetapi bisa dijadikan poin plus bagi para pustakawan dalam hal pengelolaan dan peayannannya.

47. Suroyo dan Andeka Rocky, Peran E-Journal dalam Knowledge Sharing sebagai Basis Pengelolaan Pengetahuan di Universitas Kristen Satya Wacana, Jurnal SMATIKA, Volume 06 Nomor 2 Tahun 2016 Fungsi e-jurnal sebagai Dissemination of Knowledge dan berbagi pengetahuan menjadi focus dalam artikel ini. Hal ini semakin menegaskan manfaat jurnal bagi kedinamisan dan penemuan teori baru dalam ilmu 
pengetahuan. Dalam konteks penelitian ini tentunya dalam studi Hadis.

48. lihat Ali, "Kajian Naskah Dan Kajian Living Qur'an Dan Living Hadith.”

49. Misalnya Wasisto Raharjo Jati, "Tradisi, Sunnah Dan Bid'ah: Analisa Barzanji Dalam Perspektif Cultural Studies,” El-HARAKAH (TERAKREDITASI) 14, no. 2 (June 26, 2013),; Muhammad Alfatih Suryadilaga, "Mafhūm Al-Ṣalawāt 'inda Majmū'at Joged Shalawat Mataram: Dirāsah Fī Al-Hadīth Al- Hayy,” Studia Islamika 21, no. 3 (December 30, 2014): 535-578.

50. Misalnya Ucin Muksin, "Al-Hadits dalam Pandangan Orientalis (Joseph Schacht)," Ilmu Dakwah: Academic Journal for Homiletic Studies 4, no. 11 (September 1, 2015): 111-122; Ali Mustafa Yaqub, "Autentisitas Dan Otoritas Hadis Dalam Khazanah Keilmuan Ulama Muslim Dan Sarjana Barat,” Tarjih: Jurnal Tarjih dan Pengembangan Pemikiran Islam 7, no. 1 (February 16, 2017): 33-41; Muhammad Ma'mun, "DARI MUIR HINGGA MOTZKI: Hadits dan Asal-usul Hukum Islam dalam Diskursus Orientalisme," AL-AHWAL 5, no. 1 (2013), Rohmansyah Rohmansyah, "HADIS DAN SUNNAH DALAM PERSPEKTIF IGNAZ GOLDZIHER," ULUL ALBAB Jurnal Studi Islam 16, no. 2 (December 30, 2015): 235-248; Idri Idri, "Kritik Had?th dalam Perspektif Studi Kontemporer," ISLAMICA: Jurnal Studi Keislaman 4, no. 2 (January 22, 2014): 261-279; misalnya Aan Supian, "STUDI HADIS DI KALANGAN ORIENTALISME," Nuansa 9, no. 1 (June 10, 2016),

51. Contohnya Akrimi Matswah, "HERMENEUTIKA NEGOSIATIF KHALED M. ABOU EL FADL TERHADAP HADIS NABI," ADDIN 7, no. 2 (November 14, 2015), accessed October 4, 2017, http://journal.stainkudus.ac.id /index.php/Addin/article/view/578; Ahmadi Ritonga, "KONTRIBUSI PEMIKIRAN 'ALA' AD-DIN IBN AHMAD AL-IDLIBI DALAM METODE KRITIK MATAN HADIS," AT-TAHDIS: Journal of Hadith Studies 1, no. 1 (March 31, 2017), accessed October 18, 2017, http://jurnal.uinsu.ac.id /index.php/attahdits/article/view/649; ibid.; Husna, "Kritik Matan Hadis Muhammad Syahrūr"; Moh, "MELACAK OTENTISITAS HUKUM ISLAM DALAM HADIS NABI (STUDI PEMIKIRAN JOSEPHT SCHACHT)"; Hujair AH Sanaky, "Pemikiran Fazlur Rahman Tentang Metodologi Sunnah Dan Hadis [Kajian Buku Islamic Methodology in History] | Sanaky | Al- Mawarid" (n.d.), accessed October 18, 2017, http://journal.uii.ac.id/index.php/JHI/article/view/241; Afriadi Putra, "Pemikiran Hadis KH. M. Hasyim Asy'ari dan Kontribusinya terhadap Kajian Hadis di Indonesia," Wawasan: Jurnal Ilmiah Agama dan Sosial Budaya 1, no. 1 (February 2, 2016): 46-55; Khoridatul Mudhiiah, "PEMIKIRAN DAUD RASYID TERHADAP UPAYA INGKAR SUNNAH KELOMPOK ORIENTALIS DI INDONESIA," ADDIN 7, no. 2 (November 14, 2013), accessed September 30, 2017, http://journal.stainkudus.ac.id/index.php /Addin/article/view/ 586; Amir Hamzah Nasution, "KONTRIBUSI PEMIKIRAN YUSUF AL-QARADAWI DALAM KITAB KAIFA NATA'AMAL MA'A AS-SUNNAH NABAWIYAH,” AT-TAHDIS: Journal of Hadith Studies 1, no. 1 (March 31, 2017), accessed October 18, 2017, http://jurnal.uinsu.ac.id/index.php/attahdits/ article/view/651. 
52. Misalnya Alamsyah Alamsyah, "DINAMIKA OTORITAS SUNNAH NABI SEBAGAI SUMBER HUKUM ISLAM,” AL-'ADALAH 12, no. 1 (February 28, 2017): 479-492; Zarkasih Zarkasih, "Inkar Sunah: Asal Usul dan Perkembangan Pemikiran Inkar Sunah di Dunia Islam,” TOLERANSI 4, no. 1 (May 10, 2012): 81 96; Sunusi Sunusi, "Masa Depan Hadis Dan Ulum Hadis," Al-Hikmah Journal for Religious Studies 14, no. 1 (June 13, 2013): 65-81; M. Jayadi, "Perkembangan Literatur Hadis pada Masa Awal Islam," Khizanah al-Hikmah Jurnal Ilmu Perpustakaan, Informasi, dan Kearsipan 3, no. 1 (June 23, 2015): 65-78; Masturi Irham, "Sejarah Dan Perkembangan Kritik Matn Hadis," Mutawatir 1, no. 1 (September 8, 2015): 96-112; Arifuddin Ahmad, Andi Muhammad Ali Amiruddin, and Abdul Gaffar, "Kecenderungan Kajian Hadith Di UIN Alauddin Makassar (Tracer Study Terhadap Skripsi Mahasiswa Tahun 1994-2013)," JOURNAL OF QUR'AN AND HADITH STUDIES 4, no. 2 (December 20, 2015): 249-266; Aan Supian, "Kontribusi Pemikiran Hasbi Ash-Shiddieqy Dalam Kajian Ilmu Hadis," Mutawatir 4, no. 2 (December 1, 2014): 270-291; Mudhiiah, "PEMIKIRAN DAUD RASYID TERHADAP UPAYA INGKAR SUNNAH KELOMPOK ORIENTALIS DI INDONESIA"; Missalnya Muhammad Alfatih Suryadilaga, "Ragam Studi Hadis Di PTKIN Indonesia Dan Karakteristiknya: Studi Atas Kurikulum IAIN Bukittinggi, IAIN Batusangkar, UIN Sunan Kalijaga, Dan IAIN Jember," JOURNAL OF QUR'AN AND HADITH STUDIES 4, no. 2 (December 20, 2015): 215-247.

53. Sebagai contoh Siregar, "Krtik Matan Hadis-Hadis Tentang Bid'ah"; ibid.; M. Robith Fuadi Abdullah, "Meninjau Hukuman Mati Bagi Murtad (Kajian Hadist Tematik)," Journal de Jure 4, no. 1 (June 1, 2012), Kurniati Kurniati, "Nepotisme dalam Perspektif Hadis (Kritik Sanad dan Matan Hadis)," Al Daulah : Jurnal Hukum Pidana dan Ketatanegaraan 4, no. 1 (June 20, 2015): 116-129; Warni Djuwita, "ANAK DAN PENDIDIKAN ANAK USIA DINI DALAM CAKRAWALA AL-QUR'ANHADIS," Ulumuna 15, no. 1 (June 30, 2011): 119-140; Muhammad Ansor, "ISLAM AWAL, RIDDAH, DAN PRAKSIS KEBEBASAN BERAGAMA: REINTERPRETASI HADIS MAN BADDAL DÎNAH FAQTULÛH," Mutawatir 5, no. 2 (September 28, 2016): 273-296; Umayah Umayah, "JANGAN MARAH! (ANALISIS SANAD DAN MATAN HADIS) OLEH: UMAYAH,” Diya Al-Afkar: Jurnal Studi al-Quran dan al-Hadis 2, no. 01 (June 1, 2014),; Mohamad Muhtador, "Membaca Perempuan Dalam Hadis Misoginis: Usaha Kontekstualisasi Nilai Kemanusiaan | Muhtador | BUANA GENDER: Jurnal Studi Gender Dan Anak" (n.d.) 